\title{
THE CURRENT STATUS OF INSECTICIDE RESISTANCE IN COTTON LEAFWORM Spodoptra littoralis (BOISD) IN NILE RIVER DELTA. \\ Shoaib, A. A. ${ }^{1}$; M.KH. Abbas ${ }^{1}$; F.A. Shaheen ${ }^{2}$ and M.M. Kady ${ }^{2}$ \\ 1- Plant Protection Research Institute, Ministry of Agriculture, Egypt. \\ 2- Pesticides Department, Faculty of Agriculture, Mansoura University, Egypt
}

\begin{abstract}
Two field strains of the Egyptian cotton leafworm Spodoptra littoralis (Lepidoptera: Noctuidae), collected from cotton field in mid and north of Nile River Delta, Egypt, were bioassayed for resistance to some commonly used and a candidate insecticide. Bioassay revealed that the two field strains were both with high resistance to the pyrethroid deltamethrin (RR: 10.1-14.5 fold), high tolerance to the neonicotinoid acetamiprid (RR: 7.2- 9.1) and moderate level of tolerance to the organophosphate chlorpyrifos and the carbamate methomyl (RR: $4.4-6.6$ fold); and no resistance to the new chemistry insecticide pyridalyl (RR: 1.8-1.9). Detoxification enzyme assays revealed that field strains of $S$. littoralis generally exhibit higher microsomal monooxygenase activity than the laboratory susceptible strain. However, no significant difference in carboxylesterases activity was detected. Baseline activity of acetylcholinesterase (AChE) was established and the laboratory- strain was characterized by the highest activity. Synergism investigations, using the microsomal oxidases inhibitor (Piperonyl butoxide "PBO") and the esterases inhibitor (Triphenyl phosphate "TPP"), proved that the observed levels of resistance in this pest associated with the enhanced activity of Cytochrome P450 monooxygenase. These results lead to the suggestion that rotating of pyridalyl with other insecticides that show low levels of resistance and have different modes of action may be useful for effective control of this pest.
\end{abstract}

Keywords: Spodoptra littoralis, Cytochrome P450, esterases, resistance, synergism, pyridalyl, organophosphate, carbamate, neonicotinoid.

Correspondence to:M.Kady. Department of Pesticides, Faculty of Agriculture, Mansoura University, Egypt. E-mail: kadymohamed2@yahoo.com

\section{INTRODUCTION.}

Development of resistance in cotton leafworm, Spodoptra littoralis (Biosd) to all categories of synthetic insecticides has been recorded by many investigations. In Egypt, the cotton leafworm, S.littoralis is a key polyphagus cotton pest. Its larvae only feed on cotton but also attack more than 29 hosts from other crops and vegetables, and more than 60 different cultivated and wild plants (Gordon, 1961). The rate of cotton leafworm infestation can reach up to 50,000 egg- masses/acre, causing severe damage to leaves, buds, flowers and bolls (Metcalf, 1994). Farmers often use large quantities of insecticides and spray diversity of chemicals to control this insect. In addition 
to the life cycle of this insect without hibernation period, it has destructive feeding habits and it demonstrated ability to develop resistance to chemical insecticides. Until 1968, S.littoralis was held in ceck by methylparathion, but then resistance to this compound developed. Since then, numerous other organophosphours, synthetic pyrethroid and their insecticides have been used, with appearance of resistance and cross resistance in many cases (Issa et al., 1984a; 1984b; Abo-El-Ghar et al., 1986). One of the recommended strategies to manage resistance problem is using insecticides with novel modes of action such as neonicotinoid and pyridalyl. However, monitoring efforts should be initiated before a compound is widely used and while the frequency of resistance individual is low (Ffrench -Constant. and Roush, 1990). Because, determining the range of initial resistance frequencies among insect populations facilitates early detection of changes in susceptibility to an insecticide. Therefore, surveying insect population for changes in susceptibility to insecticides is an integral component of insecticide resistance management. Early establishment of resistance baselines are critical for successful implementation of insecticide resistance management strategies before field control failures become widespread. Hence, baseline responses for laboratory and field strains of insects to novel compounds should be established to develop discriminating concentrations for monitoring programs and for historical reference values. The present study, therefore, was undertaken to analyze the current status of resistance in the Egyption Cottonworm S.littoralis in mid and north Nile River Delta. It was also of interest to evaluate the efficacy of the selected insecticides, including the new chemistry insecticide pyridalyl, to generate baseline dose-mortality responses for this insect. These data will support insecticide recommendations and provide reference dose-mortality data for future monitoring programs. In addation, the synergism of detoxification enzymes inhibitors, activites of detoxification enzymes and Acetylcholinesterase (AChE) were also analysed for demonstration of the resistance mechanism and their interaction.

\section{MATERIALS AND METHODS}

INSECT STRAINS:-

Susceptible strain-:

Egg masses of Spodoptera littoralis susceptible strain supplied from the Plant Protection Research Institute (Sakha Agricultural Research Station) Egypt were used to initiate a susceptible strain in the laboratory. Egg masses were reared in the laboratory under complete absence of insecticides to obtain the $4^{\text {th }}$ instar larvae for susceptibility tests. This strain was served as the base line reference strain for comparisons with the field strains.

Field strains:-

Spodoptera littoralis infestation in Egypt generally start at the end of march and continue until the end of November. The pest is continuously exposed to 
insecticides from April to early November, as it receives sprays first on vegetables. From vegetables the pest moves to fodder (berseem) and when cotton emerges in the field, it moves to this crop and remains feeding on it throughout the season. Growers carry out one spray per weak using a recommended field rate of an organophosphate (chlorpyrifos), a carbamates (methomyl), and one of the newer insecticides (spinosad) on cotton to control $S$. littoralis. Because these treatment regimes provide a greater chance for the generation of resistance, therefore egg masses of $S$. littoralis were collected from mid ( Gharbia "Garb-R") and north (Kafr-Elsheik "Kafr-R") Nile River Delta for bioassay evaluation. After hatching the larvae were reared in the laboratory as described by EL-Defrawy et al.(1964) to the fourth instar larvae on castor oil bean leaves (Ricinous communis) under condition of $25 \pm$ $5^{\circ} \mathrm{C}$ and $65 \pm 5 \%$ relative humidity.

\section{Insecticides and chemicals.}

Commercial formulations of insecticides used in bioassays were Chlorpyrifos ("O,O-diethyl O-(3,5,6-trichloro-2-pyridinyl) phosphorothioate" Dursban H 48\% EC, Dow AgroSciences Co.); Methomyl ("methyl N[[(methylamino)carbonyl]oxy]ethanimidothioate" Lannate 90\% SP, DuPont Co.); Deltamethrin ("1R-[1 $\left.\left.\square\left(S^{*}\right), 3 \square\right]\right]-c y a n o(3-p h e n o x y p h e n y l) m e t h y l ~ 3-(2,2-$ dibromoethenyl)- 2,2-dimethylcyclopropanecarboxylate" Decis $2.5 \%$ EC Bayer CropScience Co.); Acetamiprid ("E)-N-[(6-chloro- 3- pyridinyl)methyl]N'-cyano- $N$ - methylethanimidamide"Mosplian 25\% SP, Nippon Soda Co., Ltd Co.); Pyridalyl ("2-[3-[2,6-dichloro-4-[(3,3-dichloro-2- propenyl) oxy] phenoxy]propoxy]-5 (trifluoromethyl)pyridine "Pleo 50\% EC, Sumitomo Chemical Co. Ltd. Co.). The synergists piperonyl butoxide ("5-[[2-(2butoxyethoxy)ethoxy]methyl]-6-propyl-1,3-benzodioxole "PBO (90\%) and Triphenyl phosphate ("Triphenyl phosphate" TPP (99\%). and the detergent Triton X-100 (100\%)" octylphenol ethylene oxide condensate; Octoxynol-9, toctylphenoxypolyethoxyethanol" were obtained from Sigma Chemical Company.

\section{Toxicity bioassay.}

Bioassays were conducted using leaf dipping technique where fourth instar larvae from either the susceptible or field strains were exposed to different concentrations of the tested insecticides. Series of concentrations of each insecticide (corrected to percent active ingredient) were freshly prepared in parts per million by using distilled water. These concentrations were prepared at the mortality range which should fall between $20 \%$ and $80 \%$ (Roberton et.al 1984). Castor oil been leaves of similar size were collected from unsprayed trees, washed with distilled water and dried. The leaves were then dipped into the test solution for 10 seconds with gentile agitation and allowed to dry. Leaves immersed in distilled water only comprised the control treatments. After drying the leaves were placed into a $8 \mathrm{~cm}$ diameter transparent plastic cups, one leaf per each. Each treatment (concentration) and the control were replicated 3 times. Ten fourth-instar larvae were placed in each cup, and thus the total numbers of tested larvae per concentration was 30 . All bioassays were conducted under ambient conditions (25C으, 60\% 
R.H, and $14 \mathrm{~h}$ photo period). Larval mortality was assessed after 24-hours and the data were corrected according to Abbott's formula (1925). The estimates of $\mathrm{LC}_{50}$ values and their $95 \%$ fiducial limits were obtained by probit analysis (Finney, 1971) using Bakr LDP-line software,(2007). The resistance ratio $R$.R was calculated by dividing the $L_{50}$ of the field strain over that of the Susceptible strain.

\section{Synergism assay.}

Synergism was measured using the above described leaf dipping technique. Insecticide was applied in combination with the synergists piperonyl butoxide (PBO) (an inhibitor of cytochrome P450 monooxgyenase (Microsomal oxidases)) or Triphenyl phosphate (TPP) an esterases specific inhibitor at the maximum concentration of the synergist that caused no mortality with the susceptible or field strains. Stock solution of (PBO) and (TPP) were prepared in $99.8 \%$ acetone and then diluted by distilled water containing $0.5 \mathrm{ml} /$ liter of the emulsifying agent (Triton X-100). Breliminary experiments indicted that $100 \mathrm{mgL}-1$ synergist solutions had no toxicity against larvae of cotton leafworm. These $100 \mathrm{mgL}-1$ synergist solutions were used instead of distilled water to prepare that required concentrations of each insecticides. Control leaves were dipped in the $100 \mathrm{mgL}-1$ synergist solutions. Mortality was assessed after 24 hours. LC50 values were calculated by probit regression. Synergism ratio (S.R) was calculated by dividing the LC50 of insecticide alone by the LC50 of insecticide with the synergist. (Metcalf, 1967).

\section{Preparations of enzymes.}

Twenty $4^{\text {th }}$ instar larvae from each field strain were weighed and homogenized in chilled glass teflon tissue homogenizer (ST- 2 Mchaicpreczyina, Poland). Larvae were homogenized in distilled water $(50 \mathrm{mg} / \mathrm{ml})$ in ice-cold $67 \mathrm{mM}$ phosphate buffer (pH7.5). The homogenates were then centrifuged at 8000 r.p.m for $15 \mathrm{~min}$ at $5 \mathrm{C}^{\circ}$. The supernatants were stored at $-20 C^{\circ}$ and used as enzyme source for analysis of the activity of MFO, carcoxylesterases and acetylcholineesterase. Homogenates from susceptible strain were also prepared as previously described for comparison.

\section{Detoxification enzymes assay.}

mixed function oxidases activity.

P-nitroanisole O-demthylation was assayed to determine the oxidase activity according to the method of Hansen and Hodgson (1971) with slight modification. The standard incubation mixture contained $1 \mathrm{ml}$ sodium phosphate buffer (0.1M, pH 7.6), $1.5 \mathrm{ml}$ enzyme homogenate, 0.2mI NADPH (final concentration $1 \mathrm{mM}$ ), and $50 \mu \mathrm{g}$ glucose-6-phoshate (G-6PD). Reaction was initiated by the addition of $\mathrm{P}$-nitroanisole in $10 \mu \mathrm{l}$ of aceton to give final concentration of $0.8 \mathrm{mM}$ and incubated for $30 \mathrm{~min}$ at $37^{\circ} \mathrm{C}$. Incubation period was terminated by addition of $1 \mathrm{ml} \mathrm{HCL}(1 \mathrm{~N})$. P-nitrophenol was extracted with chloroform and $0.5 \mathrm{ml}$ of $\mathrm{NaOH}$ and absorbance of $\mathrm{NaOH}$ solution was measured at $405 \mathrm{~nm}$. An extinction coefficient of $14.28 \mathrm{M}^{-1} \mathrm{Cn}^{-1}$ was used to calculate 4-nitrophenol concentration and the activity of the enzyme was expressed as $\mathrm{n} \mathrm{mol}^{-1} \mathrm{~g}$ larvae. 


\section{Carboxylesterases activity.}

Carboxylesterases was measured according to the method described by Eguchi and Iwamoto (1975). As a substrate $5 \mathrm{mg} \beta$-naphthyl acetate in $1 \mathrm{ml}$ acetone was diluted with $25 \mathrm{ml}$ of $0.1 \mathrm{M}$ phosphate buffer, $\mathrm{pH}$ 7 and $24 \mathrm{ml}$ of deionized water. The reaction mixture contained $2 \mathrm{ml}$ of substrate and $0.2 \mathrm{ml}$ of enzyme solution. The reaction mixture was incubated at $30^{\circ} \mathrm{C}$ for $30 \mathrm{~min}$. At the end of the incubation period $0.5 \mathrm{ml}$ of $0.4 \%$ diazonium salt, Fast Blue B was added and later $0.5 \mathrm{ml}$ of $20 \%$ trichloroacetic acid. Then $4.5 \mathrm{ml}$ of ethyl acetate was added and shaken vigorously. The solution was centrifuged to separate the two layers. The upper layer of ethyl acetate and the diazo dye were removed and absorbances were recorded at $540 \mathrm{~nm}$. Standard curve of $\beta$-naphthol was used and the activity of carboxylesterase enzyme was expressed as $\mu \mathrm{g} \beta$-naphthol released / min-1/ g larva.

\section{Acetylcholinesterase (AChE) activity.}

Acetylcholineesterase (AChE) was activity measured according to the method described by Simpson et al. (1964), using Acetylcholine bromide $(\mathrm{AChBr})$ as substrate. Test tube $(\mathrm{T})$ : contain $0.2 \mathrm{ml}$ homogenate, $0.5 \mathrm{ml}$ $67 \mathrm{mM}$ phosphate buffer and $0.5 \mathrm{ml}$ Acetylcholine bromide $(3 \mathrm{mM})$. Substrate tube (S.T) contains $0.7 \mathrm{ml} 67 \mathrm{mM}$ phosphate buffer and $0.5 \mathrm{ml}$ of Acetylcholine bromide. Control tube (C) contains $0.2 \mathrm{ml}$ of enzyme homogenate and $1 \mathrm{ml}$ phosphate buffer. All test tubes were incubated exactly for 30 minutes at $37^{\circ} \mathrm{C} .1 \mathrm{ml}$ of alkaline hydroxylamine (prepared from equal volumes of $2 \mathrm{M}$ hydroxylamine chloride and $3.5 \mathrm{M} \mathrm{NaOH}$ mixed shortly before use), was added to all tubes. Tubes shaken well and allowed to stand for 2 minutes then $0.5 \mathrm{ml}$ of $\mathrm{HCl}$ ( 1 part of conc. $\mathrm{HCl}$ mixed with 2 parts of distilled water) was added. The mixture shaken vigorously and allowed to stand for 2 minutes. $0.5 \mathrm{ml}$ of ferric chloride solution $(0.92 \mathrm{M} \mathrm{FeCl} 3$ in $0.1 \mathrm{M} \mathrm{HCl})$ was added and mixed well. The resulting reaction system was then filtered through Whatman paper and absorbance of the filtrate was measured at 515 $\mathrm{nm}$. Optical densities from substrate tube (ST) and control tube(C) were subtracted from that of test tube $(\mathrm{T})$ and the enzyme activity was calculated from Acetylcholine bromide standard curve. Stock solution of $6 \times 10^{-3} \mathrm{AChBr}$ was prepared in $0.001 \mathrm{~N}$ sodium acetate. Aliquots of $0.2,0.4,0.6,0.8$ and 1 $\mathrm{ml}$ of the stock substrate solutions were transferred into test tubes and completed to $1.2 \mathrm{ml}$ by phosphate buffer. The alkaline hydroxylamine, $\mathrm{HCl}$ and the ferric chloride were added as mentioned before. The optical densities, after measuring at $515 \mathrm{~nm}$, were plotted against concentrations and the obtained curve was used to calculate the enzyme activity as $\mu \mathrm{g} \mathrm{min}{ }^{-1}$ g larva.

\section{Statistical analyses.}

Data were subjected to analysis of variance followed by Duncan's test (Duncan, 1955) and means followed by different letters are considered significant different at ( $p$ 0.05). 


\section{RESULTS AND DISCUSSIONS}

\subsection{Resistance levels.}

The toxicity of the selected insecticides against two field strains of S.littoralis was tested and the results were shown in Table (1).

As compared with the susceptible strain, it can be seen that the two field strain (Garb- strain and Kafr-strain) collected from cotton fields of mid and north of Nile Delta had developed resistance to some of the tested insecticides. Both of them were high resistant to the pyrethroid deltamethrin (RR: 10-14 fold), to AChE targeted insecticides: chlorpyrifos, methomyl, acetamipride (RR: 4-9 fold), and had no rsistance against the new chemistry insecticide pyridalyl (RR: 1.8-1.9 fold). However, Kafr-Elsheik strain seems higher tolerant (RR:5.6-9 fold) to the AChE targeted insecticides than Gharbia strain (RR: 4-7 fold).

\subsubsection{Current Status of Insecticide Resistance in Spodoptera littoralis in} mid and north Nile Delta.

The High level of resistance to the pyrethroid deltamithrin, high level of tolerance to the neonicotinoid acetamiprid, and moderate level of tolerance to the organophosphate chlorpyrifos and the carbamate methomyl in S.littoralis are in agreement with previously reported results from Egypt (Issa et al., 1984a; 1984b). Documentation of strong and widespread resistance to pyrothroid, organophosphate, organochlorine and carbamate insecticides in contemporary samples of S.littoralis accords with the studies performed by El-Guindy et al.,(2002) and Moftah and El-Awadi (2004).In the current study, it has been shown that resistance levels in both field strains of Gharbia and Kafr-El-sheik followed a consistent pattern where no significant difference were observed between the two strains in their responses to the tested insecticides. In fact this was supported by the results of Abo-El-Ghar et al., (2005), but also has been refuted by the study of El-Ghareeb and Mannaa (1989). In Cyprus, Charalambous, and lordanou (1997), observed mild resistance to methomyl and chlorpyrefos against $S$.littoralis and concluded that the use of the carbamate methomyl could result in manageable levels of resistance to S.littoralis. (Moriu et al., 2002) postulated that pyrethroid resistance can be due to modification to the target site of these insecticides or due to enhanced activity of detoxification enzymes. Similarly, the predominant mechanism of resistance to organophosphate could be also be due to enhanced activity of detoxifying enzymes Gunning et al., (2001) or due to modification of the enzyme acetylcholinesterase, which is the target site of organophosphate and carbamate insecticide (Hama 1983). Previous studies have shown that resistance to pyrethroids is associated with monooxygenases and esterases in field population of S.littoralis (Huangs and Han 2007). In the current study the neonicotinoid acetamipreid (an agonist of the nicotinic acetylcholine receptor "nAChR") was the least toxic compound tested Table (1).This may be attributed to the fact that acetamiprid is a systemic insecticide and intended to control sucking insects on crops such as
Formatted: Centered, Tab stops: $0.32 \mathrm{~cm}$ Right

Formatted: Font: $12 \mathrm{pt}$, Bold, Complex Scri Font: $12 \mathrm{pt}$, Bold 
leafy vegetables, cotton and ornamental plants. Moreover, laboratory and field strains proved to be more susceptible to the new chemistry insecticide pyridalyl. These results indicating the difficulties in achieving resistance to pyridalyl in S.littoralis in Gharbia and Kafr El-shiek strains. The biochemical mechanisms of pyridaly's insecticidal action have not been identified until now. However, its unique symptoms strongly suggest that the compound has a novel mode of action.

\section{Activities of detoxification enzymes.}

From Fig. (1.) it can be seen that activities of MFO (Fig.1.A) in field strain were significantly higher than in Lab strain. However there was no significant difference in their contents of carboxylesterases. This means that the activity enhancement of MFO was associated with the observed levels of resistance. When Gharbia and Kafr El-shiek strains compared for their enzyme activities it can be easy seen that insecticide selection had enhanced much more activity of MFO than that of esterases. This implied that MFO was more important for AChE targeted insecticides resistance than carboxyesterases. In agreement with this finding, Huang and Han (2007) showed that field strain of S.litura generally exhibit higher microsomal monooxygenase activity than the laboratory susceptible strain. Enhanced Cytochrome p450 enzymes monooxygenase activity has been shown to be a major mechanism of resistance for various insecticide classes, including organophosphates, carbamates, pyrethroids and neonicotinoids in numerous insects. In this respect, (Feyereisen, 1999, 2005; Li et al., 2007) mentioned that in many species of insects, resistance is due to the overexpression of cytochrome p450 genes resulting in the production of more Cytochrome p450 enzymes. Theoretically, overexpression could result from increases in transcription, $m$ RNA stability, and/or protein translation. However, in most cases, increased expression is due to mutations and insertions/ deletions in cis acting, promoter sequences, and/or trans-acting regulatory loci (Feyereisen, 2005; $\mathrm{Li}$ et al., 2007). The cytochrome p450 enzyme system is rather nonspecific in its attack on organic compounds. Ishaaya and Casid, 1981; Clarke et al., 1989 illustrated that mixed function oxidasessystem have many isoenzymes which all have a range of substrates and if an insecticide selects some isoenzymes which can act on different insecticides, cross-resistance might be given.

In Australia, pyrethroid resistance was proved to be caused mainly by the enhancement of esterase ( Siegfreid et al.,1990; Gunning et al.,1997) and in China, research indicated that the enhanced MFO activity was the main reason Whitten and Bull(1974); (Yang et al., 2004). Activity of Acetylcholinesterase (AChE)

The fourth instar larvae of resistante S.littoralis collected either from Gharbia or Kafr-El-Sheihk cotton fields expressed lower levels of AChE activity than the susceptible laboratory strain Fig. (1.C). In fact this was supported by Tiwari et al., (2012) but also has been refuted by other studies (Abo El-ghare et al., (2005). AChE plays a crucial role in insect cholinergic synaptic transmission and is the target site of inhibition by organophosphates and carbamates (Hama, 1983). Alteration in the structure of 
acetylcholinesterase can reduce the level of inhibition by these extensively used insecticides and confer resistance in insects and other arthropods (Oppenoorth, 1985). Although the quantitative change of AChE has been suggested to contribute to the resistance in Drosophila (Fournier et al., 1992), its structural changes is the main reason for the decreased sensitivity (Fournier et al., 1992; Zhu et al., 1996). Therefore further biochemical studies are needed to investigate the Kinetics and sensitivity of AChE in the selected field strains (Gharbia and Kafr El-Sheikh). Because measuring of Kinetic parameters of the enzyme could be used to demonstrate that the resistance strains had alternated AChE with significant insensitivity or not.
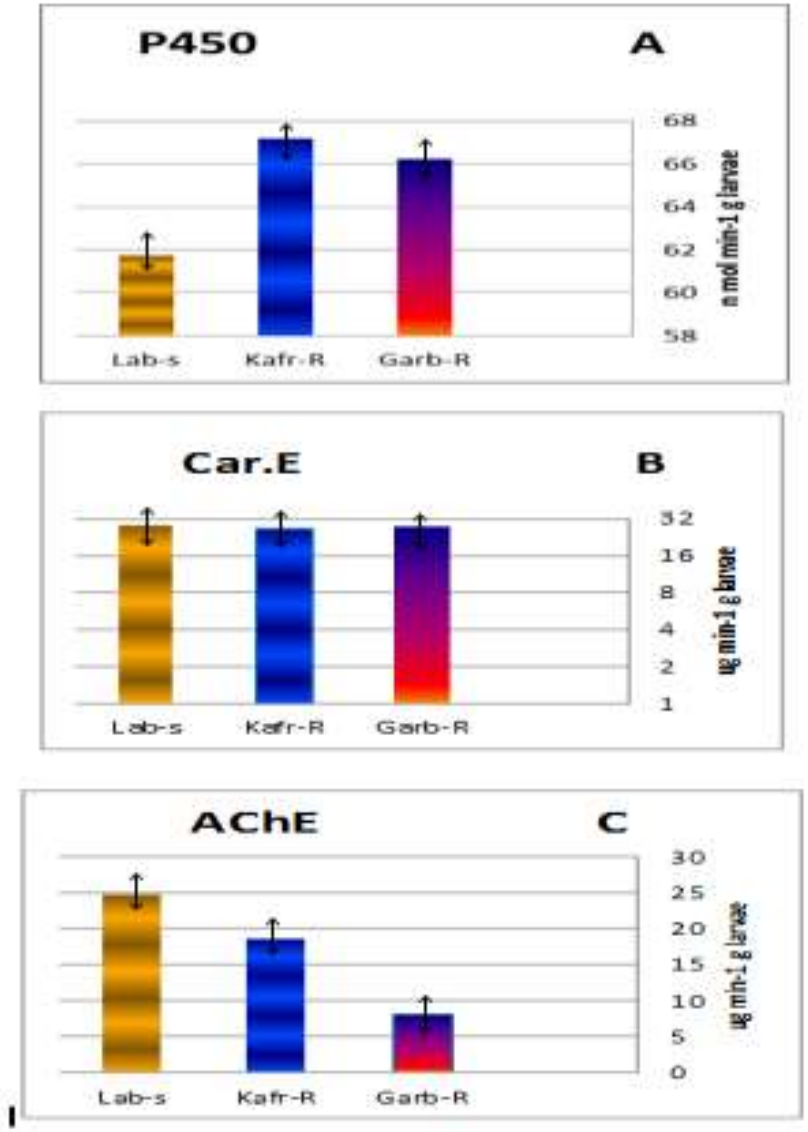

Fig. (1): Activities of Cytochrome p-450 monooxygenases ( $p 450$ ), carboxylesterases (CarE) and acetylcholinesterase (AchE) in 
the $4^{\text {th }}$ instar larvae of field and laboratory strains of S.littoralis.

Synergism of PBO and TPP.

The synergism of PBO, and TPP on the selected insecticides in the two field strains of $S$.littoralis was tested. The results were shown in Tables (2and3). As shown in Table 2, PBO showed obvious synergism on methomyl and deltamethrin and its synergistic action was approximately the same in both strains. However, it has no synergistic action with the new chemistry insecticide, pyridalyl. Similarly, as shown in Table 3, TPP was able to synergize methomyl and pyridalyl in (Garb-strain), and deltamethrin in Kafr- strain.

Table (2): Synergism of PBO on some insecticides to $4^{\text {th }}$ instar larvae of S.littoralis field strains.

\begin{tabular}{|c|c|c|c|c|}
\hline Strain $^{a}$ & Insecticides & LC50 (mgl-1) (95\%FL) & Slope \pm SE & $\mathbf{S R}^{\mathrm{b}}$ \\
\hline \multirow{10}{*}{ Garb-S } & Pyridalyl & $34.03(22.89-47.30)$ & $3.50 \pm 0.21$ & -- \\
\hline & Pyridalyl+PBO & $30.86(21.37-42.91)$ & $1.4 \pm 0.18$ & 1.1 \\
\hline & Chlorpyrifos & $88.98(69.50-116.55)$ & $2.08 \pm 0.26$ & -- \\
\hline & Chlorpyrifos+PBO & $34.48(22.68-51.07)$ & $1.13 \pm 0.15$ & 2.58 \\
\hline & Deltamethrin & $448.63(352.97-584.39)$ & $1.84 \pm 0.25$ & -- \\
\hline & Deltamethrin+PBO & 142.54(96.26-203.75) & $1.19 \pm 0.18$ & 3.14 \\
\hline & Methomyl & 439.33(299.44-745.62) & $1.18 \pm 0.18$ & -- \\
\hline & Methomyl+PBO & $156.80(108.64-225.99)$ & $1.21 \pm 0.17$ & 2.80 \\
\hline & Acetamiprid & $5735.20(4899.37-7290.84)$ & $2.95 \pm 0.51$ & -- \\
\hline & Acetamiprid+PBO & $3082.47(2447.23-3743.18)$ & $2.21 \pm 0.37$ & 1.85 \\
\hline \multirow{10}{*}{ Kafr- S } & Pyridalyl & $35.54(21.46-56.01)$ & $1.13 \pm 0.25$ & -- \\
\hline & Pyridalyl+PBO & $33.28(21.77-49.39)$ & $1.12 \pm 0.15$ & 1.06 \\
\hline & Chlorpyrifos & $109.20(81.40-149.33)$ & $1.57 \pm 0.19$ & -- \\
\hline & Chlorpyrifos+PBO & $43.57(30.75-61.06)$ & $1.38 \pm 0.18$ & 2.5 \\
\hline & Deltamethrin & 641.07(499.51-892.66) & $1.82 \pm 0.28$ & -- \\
\hline & Deltamethrin+PBO & $216.22(139.30-351.18)$ & $0.95 \pm 0.17$ & 2.96 \\
\hline & Methomyl & $592.07(340.52-1216.92)$ & $0.924 \pm 0.10$ & -- \\
\hline & Methomyl+PBO & $103.28(73.81-148.50)$ & $1.29 \pm 0.13$ & 5.44 \\
\hline & Acetamiprid & $6730.69(4859.92-12107.88)$ & $1.44 \pm 0.28$ & -- \\
\hline & Acetamiprid+PBO & $4389.77(2423.35-5742.32)$ & $1.09 \pm 0.19$ & 1.92 \\
\hline
\end{tabular}

a =Lab-s, laboratory susceptible strain; Garb-S, Gharbia field strain ; Kafr- S, Kafr EISheikh field strain

b- $\mathbf{R R}=$ syneregestic ratio $=L_{50}$ value of insecticide alon $/ L_{50}$ value of insecticide+ synergist.

PBO, TPP are considered to be inhibitors of MFO and esterases, respectively. Therefore, the resistance associated increase in synergism of 
PBO and TPP indicated that enhanced MFO and esterases activity, might contribute to the resistance in this pest.

\begin{tabular}{|l|l|c|c|c|}
\hline Strain $^{\text {a }}$ & \multicolumn{1}{|c|}{ Insecticides } & LC50 (mgl-1) & Slope \pm SE & SR $^{\mathbf{b}}$ \\
\hline \multirow{5}{*}{ Garb-S } & Pyridalyl & $34.03(22.89-$ & $3.50 \pm 0.21$ & -- \\
\cline { 2 - 5 } & Pyridalyl+ TPP & $10.13(3.61-$ & $0.639 \pm 0.81$ & 3.35 \\
\cline { 2 - 5 } & Chlorpyrifos & $88.98(69.50-$ & $2.08 \pm 0.26$ & -- \\
\cline { 2 - 5 } & Chlorpyrifos+ TPP & $53.59(36.93-$ & $1.22 \pm 0.17$ & 1.66 \\
\cline { 2 - 5 } & Deltamethrin & $448.63(352.97-$ & $1.84 \pm 0.25$ & -- \\
\cline { 2 - 5 } & Deltamethrin+ TPP & $332.97(238.87-$ & $1.30 \pm 0.21$ & 1.34 \\
\cline { 2 - 5 } & Methomyl & $439.33(299.44-$ & $1.18 \pm 0.18$ & -- \\
\cline { 2 - 5 } & Methomyl+ TPP & $126.02(91.80-$ & $1.40 \pm 0.18$ & 3.48 \\
\cline { 2 - 5 } & Acetamiprid & $5735.20(4899.37-$ & $2.95 \pm 0.51$ & -- \\
\cline { 2 - 5 } & Acetamiprid+ TPP & $4225.57(3335.58-$ & $1.74 \pm 0.35$ & 1.27 \\
\hline \multirow{5}{*}{ Kafr- S } & $35.54(21.46-$ & $1.13 \pm 0.25$ & -- \\
\cline { 2 - 5 } & Pyridalyl & $20.8(8.51-38.94)$ & $0.71 \pm 0.14$ & 1.7 \\
\cline { 2 - 5 } & Cyridalyl+ TPP & $109.20(81.40-$ & $1.57 \pm 0.19$ & -- \\
\cline { 2 - 5 } & Chlorpyrifos & $1.03 .51(77.89-$ & $1.82 \pm 0.23$ & 1.05 \\
\cline { 2 - 5 } & Delorpyrifos+ TPP & $641.07(499.51-$ & $1.82 \pm 0.28$ & -- \\
\cline { 2 - 5 } & Deltamethrin & $317.90(233.54-$ & $0.925 \pm 0.18$ & 2.03 \\
\cline { 2 - 5 } & Methomyl & $592.07(340.52-$ & $0.924 \pm 0.15$ & -- \\
\cline { 2 - 5 } & Methomyl+ TPP & $421.54(279.84-$ & $1.082 \pm 0.17$ & 1.40 \\
\cline { 2 - 5 } & Acetamiprid & $6730.69(4859.92-$ & $1.44 \pm 0.28$ & -- \\
\hline
\end{tabular}

Table (3): Synergism of TPP on some insecticides to $4^{\text {th }}$ instar larvae of S.littoralis field strains. 


\begin{tabular}{|l|l|l|l|l|}
\hline & Acetamiprid+ TPP & $3997.54(3180.16-$ & $1.82 \pm 0.35$ & 1.68 \\
\hline
\end{tabular}

a =Lab-s, laboratory susceptible strain; Garb-S, Gharbia field strain ; Kafr- S, Kafr ElSheikh field strain

b- $R R=$ syneregestic ratio $=L_{50}$ value of insecticide alon $/ L C_{50}$ value of insecticide+ synergist.

1- $\quad$ The use of synergists to enhance insecticide toxicity (El-sebae et al., 1978, Riskallah et al., 1984; Abd-Elghafar et al., 1993) especially PBO to inhibit the defence enzymes mixed function oxidase Wilkinson (1976) are well established strategies to manage resistant insect pest. Treatments using deltamethrin, methomyl, chlorpyrifos and acetamiprid mixed with PBO suppressed the resistance in the S.littoralis population indicating that $\mathrm{P} 450$ complex of MFO (monooxygenases) is a factor responsible for resistance to these insecticides. Mixed function oxidases play a significant role in degradation of pyrethroid insecticides Yamamoto (1973) or organophosphorus insecticides (Attia and Frecker 1984) and neonicotinoids (Nauen et al., 1996; Mota-Sanchez et al., 2000). Enhanced cytochrome P450 monooxygenase activity has been shown to be a major mechanism of resistance for pyrethroids in numerous insects such as S.littoralis (El-sayed et al., 1982; Riskallah et al., 1984) H.armigera (Yang et al., 2004, 2005; Chen et al., 2007) and Anopheles sinensis Chang et al., (2013). Piperonyl butoxide (PBO) synergist increased the insecticidal activity of chlorpyrifos in the tested strains. Whitten and Bull (1974), concluded that the major factor responsible for resistance in Heliothis virescens against chlorpyrifos was the greater activity of the microsomal oxidase in the resistant caterpillars. The significant increase in efficacy of acetamiprid by $\mathrm{PBO}$ in the resistant field strains S.littoralis proved the involvement of cytchrome P-450monooxygenase in acetamiprid resistance. Similar results were obtained by Ninsin and Tanaka 2005 with acetamiprid on a laboratory colony of diamondback moth Plutella xylostella. In the present study PBO produced no synergism with pyridalyl in Gharbia and Kafr El-Sheikh field strains, while TPP slightly enhanced the efficacy of this insecticide. It seems likely that pyridalyl has a different biochemical mode of action from any insecticides tested and this may explain why pyridalyl was highly active against the S.littoralis when compared with the other insecticides. Similarly, Saito and Sakamato 2008, reported that pyridalyl was highly active against resistant population of the diamonond back P.xylostella, which shows high resistance against conventional insecticides. The biochemical mechanisms conferring toxicity to pyridalyl have not yet been elucidated in detail, but some studies suggested a possible involvement of microsomal monooxygenases. Powell et al., (2011) illustrated that pyridalyl action requires cytochrome P-450 activity, possibly for production of a bioactive derivative, and pyridalyl metabolism being prevented by general P-450 inhibitors. They also postulated that cytochrome P-450 action leads to an active pyridalyl metabolite, which results in production of reactive oxygen species (ROS), that leads to damage of cellular macromolecules (e.g., proteins) and enhanced proteasome activity leads to increased protein 
degradation and necrotic cell death. Pyridalyl is an ether compound, although ethers resist undergoing hydrolysis, they are often cleaved by acids. Nagahori et al., (2009) showed that the biotransformation reaction for pyridalyl in rats is proposed to be cleavage of the ether linkage between the dichloropropenyl group and the dichlorophenyl group to form S-1812-DP (M3), which was the major metabolite in feces and urine. They concluded that further investigations are required to clarify species- related differences in rates of $O$-dealkylation of the allyl and alkyl ethers and determination of the various cytochrome P-450 enzymes involved in the metabolism of pyridalyl.

Cytochrome P-450 monooxygenases, is a nonspecific enzyme system attack functional groups of insecticides rather than specific molecules. A synergism of the carbamate (methomyl), the synthetic pyrethroid (deltamethrin), the organophosphate (chlorpyrifos) and the neonicotinoid (acetamiprid) by PBO and to some extent by TPP in the same populations of S.littoralis tested suggests that these classes of insecticides are crossresistant due to a common mechanism of metabolic detoxification by cytochrome P-450 monooxygenases and esterases. This cross-resistance could probably extends to the novel insecticide, pyridalyl. However (Saito et al., 2002; Isayama et al., 2005) have reported that pyridalyl, has no crossresistance till now with any other class of insecticide. Because the use of new insecticides with a mode of action that differs from existing insecticides is highly desirable. Therefore pyridalyl is expected to take an important role in IPM $\mathrm{S}$ and insecticide- resistance management programs. However, Ahmed (2009) notified that the valuable new compounds should be applied judiciously and their useful life can be prolonged by limiting their application to one or two spray per season on a single crop. Based on the present results we can suggest that rotating of pyridalyl with other insecticides that show low levels of resistance and have different modes of action may be useful for effective management of cotton leafworm Additional it is important to notify that such new chemicals must be subjected to early and continues field monitoring programs. Because early detection of resistance would permit changes in strategy, most likely involving a change in the pesticide used, to prevent further resistance development.

\section{REFERENCES}

Abbott, W. S. (1925). A method of comparing effectiveness of an insecticide. J. Econ. Entomol. 18: $265-267$.

Abo Elghar, G. A; Z. A. Elbermawy; A. G. Yousef and H. K. Abd-Elhady (2005). Monitoring and characterization of insecticide resistance in the cotton leaf worm Spodoptera littoralis (Boisd). (Lepidoptera: Nocuidae). J. Asia. Pacific. Entomol. 8 (4): 397 - 410.

Ahmad, M. (2009). Synergism of insecticides by enzyme inhibitors in the resistant population of Spodoptera litura (Lepidoptera: Noctuidae). J. Acta. Entomol. Sic. 52 (6): $631-639$. 
Abd-Elghafar S.F., Knowles C.O., Wall M.L. 1993. Pyrethroid resistance in two field strains of Helicoverpa zea (Lepidoptra: Noctuidae).J. Econ. Entomol. 86: 1651-1655.

Attia F.L.and Frecher T. 1984. Cross-resistance spectrum and synergism studies in organophosphorus- resistance strain of Qryzaephilus surinamensis (L) (Coleoptera: Cucujidae) in Australia. J.Econ.Entomol.77(3):1367-1370.

Bakr E, LdP Line, 2007. [Online]. Available: http://embakr.tripod. com/ldpline/index.htm].

Chang XL, Xue YQ, Zhang AD, Zhu GD, Fang Q. Zhongguo Xue Xi Chong Bing Fang Zhi Za Zhi. 2013 Jun;25(3):263-7. Chinese.

Chen, M., Han, Z.,Quiao, X., and Qu, M.(2007). Resistance mechanisms and associated mutations in acetylcholinesterase in Sitobion avenae (Fabricius), Pestic. Biochem. Physiol., 87,189.

Charalambous, P. and N. Iordanou (1997). Response of susceptible and resistant strains of Spodoptera littoralis to conventional insecticides in Cyprus. Technical Bulletin 179, 7p.

Clarke S.E., Brealey C.J. and Gibson G.G. (1989). Cytochrome P450 in the housefly induction, substrate specificity and comparison to three rat hepatic isoenzymes, Xenobiotica (19) 1175-1180.

Duncan, D.B. (1955). Multiple ranges and multiple F. test. Biometrics, 11: 142.

Eguchi, M. and A. Iwamoto (1975). Changes in protease, esterase, and phosphatases in the alimentary canal of the silkworm during metamorphosis. J. Insect. Biochem. 5: 495 - 507.

El- Ghareeb, A. M. and S. H. Mannaa (1989). Insecticidal potency and development of resistance in the cotton leaf worm in Upper Egypt. J. Assiut. Agric. Sci. 20 (2) : $373-387$.

El-Defrawy, M. E.; A. Toppo Zada; N. Mansour; and M. zied (1964). Toxicological Studies on the Egyptian cotton leaf worm Prodenia liturea susceptibility of different larval instar of P.Litura to insecticides. J. Econ. Entomol. 57: 591 - 593. Entomo.7: 167 - 173.

El-Guindy, M.A.; Y.F. Ghoneim, M. Singab and M.M. Abdel-Star (2002) History of resistance to pyrethroids in field strains of Spodoptera littoralis (Boisd.) over a period of twenty years (1979-1999). Annals of Agric. Sc. Moshtohor, 40(1): 615-628.

El-Sayed E.L., Abdel-Sattar M.M. and Mohanna H.H. (1982). Influence of three synergist on the action of some insecticides against parental and resistance strains of the Egyption cotton leafworm. Experientia, 38:1 083-1 084.

El-Sebae A.H., Dawood A.S. ; Saliman S.A 1978. New synergists for synthetic pyrethroids and organophosphorous insecticides against cotton leafworm, Spodoptera littoralis. Med. Fac. Landbouww. Rijksunvi. Gent. 43/2:873-880.

Feyerisen, R., 1999. Insect P450 enzymes, Annu. Rev. Entomol., 44, 507. 
Feyerisen, R., 2005. Insect Cytochrome P450, in Comprehensive molecular insect science, Gilbert, L.I., latrou,K., and Gill, s.s., Eds., Vil.4, London: Elsevier, P.L.

Ffrench -Constant. R.H. and R.T. Roush. (1990). Resistance detection and documentation: the relative roles of pesticidal and biochemical assays, pp.-4-38 In R.T. Roush and B.E. Tabashnik [eds.],Pesticide Resistance in Arthropods. Chapman and Hall, New York, NY.

Finney, D. J., Probit analysis, 3rd ed., Cambridge: Cambridge University press 1971

Fournier, D.J. Bride, M., Hoffmann F. and Karch F.(1992). Acetylcholinesterase. Two types of modifications confer

Gordon, H. T. (1961). Nutritional factors in insect resistance to pesticides Ann. Rev. Entomol. 6: $27-54$.

Gunning R.V., Moores G.D. and Devonshire A.L. (1997). Esterases and fenvalerate resistance in a field population of Helicoverpa punctigera (Lepidoptera: Noctuidae) in Australia, Pestic. Bichem. Physiol. (58) 155-162.

Gunning, R.V. and Moores, G.D. (2001). Insensitive acetylcholinesterase as sites for resistance to organophosphates and carbamates in insect: insensitive acetylcholinesterase confers resistance in Lepidoptera, in Biochemical sites of insecticide action and resistance, Ishaaya, I., Ed., BERLIN: Springer-Verlag, P.221.

Gunning, R. V., H. T. Dang, F. C. Kemp, 1. C. Nicholson, and C. D. 'Moores. 2005. New resistance mechanism in Helcoverpa armigera threatens transgenic crops expressing Bacillus thuringiensis CrylAc toxin. Appt. Environ. Microbial. 71: 2558-2563.

Hama, H. 1983. Resistance to insecticides due to reduced sensitivity of acetylcholinesterase pp. 299 -331. In G. P. Georghiou and T. Saito [eds.], Pest resistance to insecticides. Plenurn, New York.

Hansen, I. G. and E. Hodgson (1971). Biochemical Characteristics of insect microsomes. N- and - O-demethylation. Biochem, Pharachol. 20: 1569 -1678 .

Huangs, S. J., and Z. J. Han. 2007. Mechanisms for multiple resistances in field populations of common cutworm, Spodoptera. litura (Fabricius) in China. Pestic. Biochem. Physiol. 87: 14-22.

Ishaaya I. and Casida J.E. (1981). Pyrethroid esterase(s) may contribute to natural pyrethroid tolerance of larvae of the common green lacewing, Environ.Entomol. (10) 681-684.

Isayama, S.; S. Saito; K. Kuroda; K. Umeda and K. Kasmastsu (2005). Pyridalyl, a novel insecticide: potency and insecticidal selectivity. J. Insect. Biochem. Phytio. 58: 226 - 223.

Issa, Y.H.; Keddis, M.E.; Abdel-Sattar, M.A.; Ayad, F.A.; El-Guindy, M.A. $\left(1984^{\mathrm{a}}\right)$ Survey of resistance to organophosphorus insecticides in field strains of the cotton leafworm during 1980-1984 cotton-growing seasons. Bulletin of the Entomological Society of Egypt, Economic Series 14, 399-404. 
Issa, Y.H.; Keddis, M.E.; Abdel-Sattar, M.A.; Ayad, F.A.; El-Guindy, M.A. $\left(1984^{\mathrm{b}}\right)$ Survey of resistance to pyrethroids in field strains of the cotton leafworm during 1980-1984 cotton-growing seasons. Bulletin of the Entomological Society of Egypt, Economic Series 14, 405-411.

Li, X., Schuler, M.A., and Berenbaum, M.R. 2007. Molecular mechanisms of metabolic resistance to Synthetic and natural Xenobiotics, Annu. Rev. Entomol., 52,231.

Metcalf, R. L. (1967). Mode of action of insecticide synergists .J. Ann. Rev. Entomol. 12: 229- 256.

Metcalf, R. L. (1994). Insecticide in pest management in: introduction to insect pest management. $3^{\text {rd }}$ Edited by Robert. L., Metcalf and William H.Luckmann. John, Wily \& Sons Inc. $245-284$.

Moftah, S. A and I. OEL - Awami (2004). Toxicity evaluation of some insecticides to the cotton leaf worm Spodoptera littoralis (Biosd) and determination of their residues in the field and Greenhouse. J. Alex. Agric. Res. 49(2): $65-74$.

Mota-Sanchez D., Whalon M., Grafius E.,Hollingwoth.R. 2000. Resistance of Colorado potato beetle to imidacloprid. Resist. Pest Manage. Newsletter $11(1) ; 32-34$.

Moriu, S., M. S. Williamson, S. J. Goodson, J. K. Brown, B.E. Tabashnik, and T. J. Dennehy. 2002. Mutations in. the Bemisia tabaci para sodium channel gene associated with resistance to a pyrethroid plus organophosphate mixture. Insect Biochem. Mol. Biol. 32: 1781-1791.

Nagahori H, Tomigahara Y, Isobe N; Kaneko H. 2009. Metabolism of pyridalyl in rats: excretion, distribution, and biotransformation of dichloropropenyl - labeled Pyridalyl. J. Agric. Food chem. 2009 Nov 25;57(22): 10845-51. doi: 10.1021/jf 9026469.

Nauen R., Strobel J., Tietjen K.,Erdelen C., Elbert A. 1996. Aphicidal activity of imidacloprid against a tobacco feeding strain of Myzus persicae ( Homoptera: Aphididae) from Japan closely related to Myzus nicotiana and highly resistance to carbamates and organophosphates. Bull.Entomol. Res.86:165-171.

Ninsin, K. D. and T. Tanaka (2005). Synergism and Stability of acetamipird resistance in a laboratory colony of plutella xylostella. J. Pest. Manag. Sci 61: $723-727$.

Oppenoorth FJ, 1985. Biochemistry and genetics of insecticide resistance. In: Comprehensive insect physiology, biochemistry and pharmacology ,Kerkut G.A. and Gilbert LI, eds. Oxford: Pergamon Press; 731-773.

Powell, G.F. D.A.Ward, M.C.Prescott, D.G. Spiller, M.R.H.White, P.C.Turner,F.G.Earley, J.Phillips; H.Rees.2011. The molecular action of the novel insecticide, Pyridalyl. Insect Biochemistry and Moleular Biolgy. Volume. 41, issue 7, Jule, pages 459-69.

Riskallah M.R., Abo-Elghar M.R., Radwan H.S.A., Nassar M.E. Abd-Elghafar S.F.1984. Effects of different synergists on the toxicities of fenvalerate 
and decamethrin to susceptible and pyrethroid-resistance. Int. pest Control 6:37-40.

Robertson, J. L.; K. C. Smith; N. E. Savin and R. L. Lavigne (1984). Effects of dose selection and sample size on the precision of lethal dose estimates in dose - mortality regression .J. Econ. Entomol. 77: 8331984.

Saito S, Isayama S, Sakamoto N, Umeda K, Kasamatsu K.2002. Pyridalyl (S1812); A novel insecticidal agent for controlling lepidopterous pests. Proc. Brighton Crop Protection Conference Pests Dis p 33-38.

Saito,S., N. and Sakamoto.(2008). Pyridalyl: Discovery, Insecticidal Activity, and Mode of Action in Modern Crop Protection Compounds. pp. 11111119.Edited by Wolfgang Krämer and Ulrich Schimer.

Siegfreid B.D., Scott, J.G., Roush, R.T and Zeichner, B.C. (1990). Pestic. Biochem. Physiol.38, 110-121.

Simpson, D. R.; D. L. Eull and D. A. Linguist. (1964) A semimicrotechnique for estimation of cholinesterase activity in boll weevils. J. Ann. Ent. Soc. Amer., 57: 367-371.

Tiwri, S.; Lukasz L.S. and Michael E.R. (2012). Biochemical Basis of Organophosphate and Carbamate Resistance in Asian Citrus psyllid. Entomological Society of America 105(2): 540-548.

Whitten, C.J., and D.L.Bull.(1974 $\left.{ }^{\mathrm{a}}\right)$. Comparative toxicity, absorbtion, and metabolism of chlorpyrifos and its dimethyl homologue in methyl parathion resistant and susceptible tobacco budworm. Pestic. Biochem. Physiol., 4:266-274.

Wilkinson C.F.(ed.).1976. Insecticide Biochemistry and Physiology. Plenum, New York, $768 \mathrm{pp}$

Yamamoto I. 1973. Pyrethroid insecticides and the synergists action and metabolism. J. Agric.Sci. Tokyo. Nogyo. Diagaku 17:273-313.

Yang Y., Wu Y. Chen S. Devine. G.J. Denholm I. Jewess P. and Moores G.D.(2004). The involvement of microsomal oxidases in pyrethroid resistance in Helicoverpa armigera from Asia. Insect Biochem. Mol. Boil. (34) 763-773.

Yang E., Yang Y., Wu S. and Wu Y. 2005. Relative contribution of detoxifying enzymes to pyrethroid resistance in a resistant strain of Helicoverpa armigera. J. Appl. Entomol., 129:521-525.

Zhu, K.Y., Lees, S.H., and Clark, J.M.(1996). Apoint mutation of acetylcholinesterase associated with azinphosmethyl resistance and reduced fitness in Colorado Potato beetle, pestic. Biochem. Physiol., 55,100 .

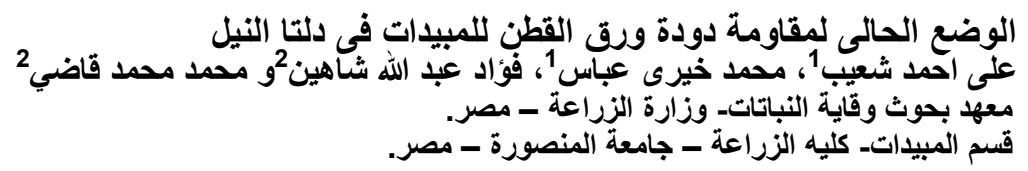




\section{J. Plant Prot. and Path., Mansoura Univ., Vol.5 (1), January, 2014}

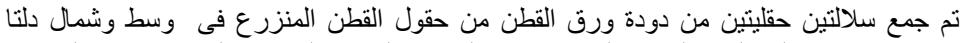

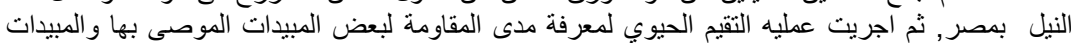

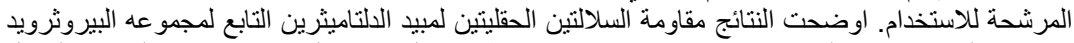

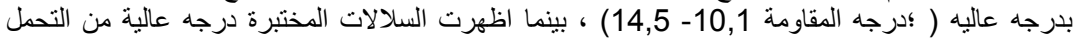

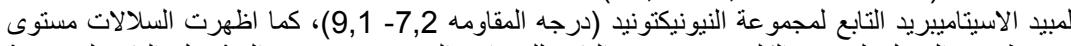

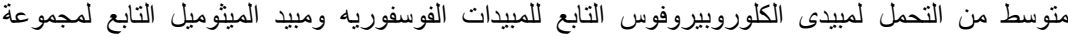

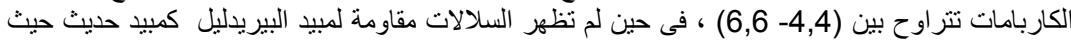

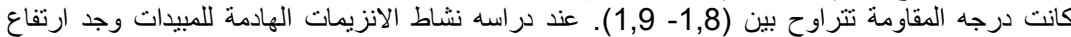

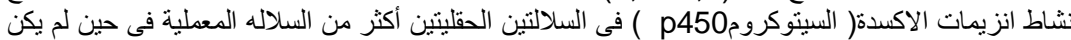

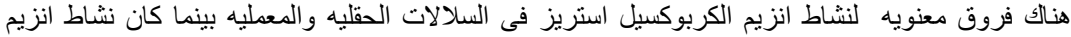

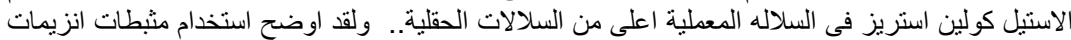

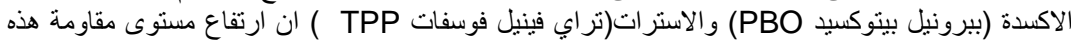

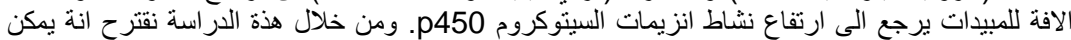

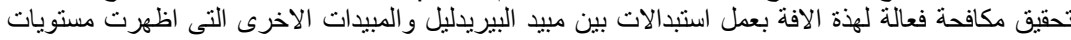
مقاومة منخفضة وتختلف فى طريقه احداثها لفعلها السام.

كلية الزراعة - جامعة المنصورة كلية الزراعة - جامعة الاسكنة جامعة المنصوريه
قام بتحكيم البحث

أ.د / سلوى السعيد نجم الـديث

أ.ـد / نادرشاكر يوسف الديد 
Shoaib, A. A. et al. 